解 説

\title{
工学系アカデミック・ロードマップ 一2050年の社会を見据えて一
}

Academic Roadmap of Robotics from the Viewpoint of Engineering -What happen in 2050?-

内 山 隆*1 金子 真 $* 2$ 國 井 康 晴*3 ${ }^{* 1}$ 富士通 ${ }^{* 2}$ 大阪大学 ${ }^{* 3}$ 中央大学 Takashi Uchiyama*1, Makoto Kaneko*2 and Yasuharu Kunii ${ }^{* 3}{ }^{* 1}$ Fujitsu Laboratories Ltd. ${ }^{* 2}$ Osaka Universiy ${ }^{* 3}$ Chuo Universiy

\section{1.は じめに}

本稿は日本ロボット学会が中心となって行った 2050 年 を見据えた工学系アカデミック・ロードマップ (平成 19 年 度版）の報告書 $[1]$ が，どのような考え方でテーマが選定さ れ，かつどのようにまとめられたのか，ポイントを絞って 解説してみたい.

\section{2. まとめ方の基本方針}

一般に政府が行う研究開発投資はその時代のニーズに沿っ た形で進められる。そうだとすると 2050 年に遭遇してい る社会を想定することなしに 42 年後のロボットのアカデ ミック・ロードマップを描いても机上の空論になりかねな い.このような点を踏まえ, 本委員会 (委員長: 内山隆, 副 委員長：金子真, 幹事：國井康晴）では最初に 2050 年にお ける社会がどんな問題に遭遇しているのかという点につい て議論し, 結果的に少子高齢化, エネルギー問題, 環境問 題という三つのキーワードがピックアップされた.

少子高齢化：日本は 2050 年に，人口の 3 人に 1 人が 65 歳 以上という超高齢化社会に突入する。このような超高齢化 社会では，二つの問題が顕在化する。一つは若手労働者人 口の減少に伴う生産性低下が引き起こす問題，もう一つは 高齢者の生活支援に関する問題である．前者に対処するに は生産工程および検査診断工程の自動化・効率化が重要な 課題となる。また後者に対処するためには, 生活空間の高 度情報化技術，高齢者の高度運動支援技術，さらに医療 . 介護支援システムの高度化技術が重要となるであろう.

エネルギー問題：石油枯渇問題がさらに現実味を帯びてく る.このようなエネルギー問題に対しては二つの対抛法 が考えられる。一つはいかにして石油エネルギーを節約す るかという低消費・高効率機器設計に関する対処法で，もう

\footnotetext{
原稿受付 2008 年 7 月 28 日

キーワード : Academic Roadmap, Robotics, Engineering

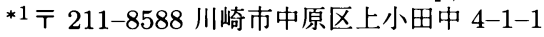

*2 $\bar{\top}$ 565-0871 吹田市山田丘 2-1

*3 个 112-8551 文京区春日 1-13-27

${ }^{* 1}$ Nakahara-ku, Kawasaki-shi, Kanagawa

*2 Suita-shi, Osaka

${ }^{* 3}$ Bunkyo-ku, Tokyo
}

ARM2008 - エ学系WGイメージ图

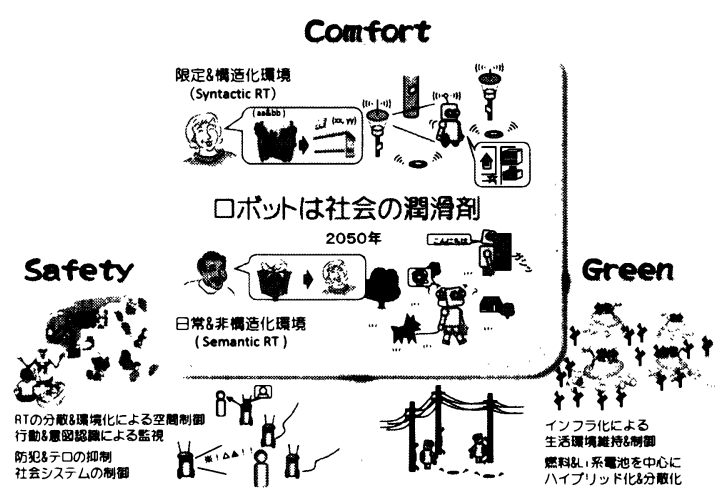

図 1 CSG のイメージ図

一つは太陽光発電, 風力発電といった石油代替エネルギー の利用技術開発による対処法である.

環境問題：地球温暖化に伴う地球規模の環境問題は今後ま すますクローズアップされてくることは間違いない.この ような地球環境の変化をどうモニタリングし，二酸化炭素 排出抑制をどう実現していくのか, 今日よりもさらに切実 な問題が突きつけられるであろう.

すべての色は 3 原色で構成されているように，上記三つ のキーワードで代表される社会的問題は社会生活の営みと いう観点から単純なキーワードでまとめなおすことができ る. 委員会では, 光の 3 原色 (RGB) とのアナロジーで, 社会生活の営みの 3 原単語として快適 ( $\mathrm{C}:$ Comfort), 安 全安心 (S:Safety), 効率 (G:Green) の頭文字をとって CSG を選定した。これらのキーワードにはそれぞれ次のよ うな願いが込められている。

快適（Comfort；C）〔少子高齢化社会，エネルギー問題， 環境問題が想定されるなかにおいても快適に生活したい.

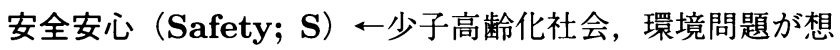
定されるなかにおいても安全・安心を確保したい.

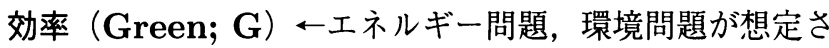
れるなかにおいても緑を確保したい.

図1はCSGをイメージ図に描いたものである. 


\section{3． 執筆者と執筆内容}

原稿を執筆していただいた方々（敬称略）のタイトルおよ び2050年で予測される代表的技術について以下にまとめて 拉きたい.ここで C, S , G はそれぞれ Comfort, Safety, Greenの視点で原稿がまとめられたことを示している.

\section{1 サービス}

山田陽滋 (産総研) : 安全安心ロボティクス $(\mathrm{S})$; ロボッ トと人間との共存を前提とした安全性評価が加速する。則 次俊郎 (岡山大学) : やわらかいロボットシステム $(\mathrm{C}, \mathrm{S})$; 高分子ゲルなどの機能性材料を用いた人工筋肉がロボット 用アクチュエータとして用いられるようになる。 小林政巳 (川崎重工業) : 未来の産業用ロボット $(\mathrm{C}, \mathrm{S})$; 機能的には 高度な判断・推論を行いかつ複雑な作業を実現する産業用 ロボットが出現する. 田中雅人 (安川電機) : 未来のサービ スロボット $(\mathrm{C}, \mathrm{S})$; 高度な推論機能が組み込まれた家庭 内サービスロボットが出現する。鎌田実 (東大), 岡部康平 (東大) : 個人モビリティ拡張システム $(\mathrm{C})$; パワードスー ッと移動ロボットが融合したような服装感覚タイプの個人 モビリティスタイルが見られるようになる。小林宏（東理 大) : 人間の能力拡張 (運動, 代謝, 感覚) (C) ; 生体信号 を使って装着型ロボットが自由に操れるようになる。

\section{2 センシング\&知能}

沢崎直之 (富士通) : 三次元ビジョン・人間をみるとは? $(\mathrm{C}, \mathrm{S})$; 人の実時間高精細モデルを利用して人の微細な動 きや表情の解析ができるようになる。倉爪亮（九大）：ロー カライゼーション $(\mathrm{C})$; 記憶と推論に基づく位置同定やセマ ンティック位置認識ができるようになる。池内克史 (東大)： 操作のためのモデル化技術 (C) ; 1,000 フレーム/秒, ミタ ロンオーダの精度で検出できるハイダイナミックレンジカ メラを使って高速・高精度なモデリングが実現できるよう になる。中内靖 (筑波大) : 環境構造化による構造認識 (C, S) ; 全行動情報がデータベース化され，生理状態理解，心的 状態理解に基づくセマンティック行動理解が可能になる。下 倉健一郎 $(\mathrm{ATR})$ ：ネットワークロボット $(\mathrm{C}, \mathrm{S})$; 仮想空間
と穾空間とのリアルタイム融合が可能になる。佐久間一郎 (東大) : 未来医療システム $(\mathrm{S})$; 診断と治療が同時に行わ れるカプセル型診断・治療装置の実用化が見込まれている.

\section{3 ヒューマノィド}

梶田秀司 (産総研)：ヒューマノイド (移動) (C)；フル充 電で $700[\mathrm{~km}] （ 10[\mathrm{~km} / \mathrm{h}]$ 歩行時）かつハードル走ができ る超人的移動能力をもったヒューマノイドロボットが出現 する。杉原知道 (九大) : ヒューマノイド技術（全身）(C)； 可搬重量 $100[\mathrm{~kg}]$ で $10[\mathrm{~km} / \mathrm{h}]$ 走行可能なヒューマノイド ロボット（重量 $30[\mathrm{~kg}]$ 程度）が実現可能.

\section{4 ロコモーション\&マニピュレーション}

安積欣志 (産総研) : 高分子アクチュエータ (人工筋肉) (S， G) ; 化学エネルギー高効率変換材料が開発され, 口 ボット用人工筋肉だけでなく人工内臓にも使われるように なる. 小俣透 (東工大) : マニピュレーション $(\mathrm{C}, \mathrm{S})$; 指先 力 $100[\mathrm{~N}]$ を発生できるロボットハンドで人間を超えるマニ ピュレーションが実現できるようになる。 小森谷清（産総 研)：ロコモーション $(\mathrm{C})$; 屋内外の一般環境下でのロボッ トナビゲーションが可能になる。曽根理嗣 (JAXA)：エネ ルギー $(\mathrm{C})$; 充電インフラが社会的に整備され, ロボット の自立的な判断によってエネルギーが確保できるようにな る.八木透 (東工大) : 細胞とデバイスが融合したバイオ八 イブリッド型神経インタフェースが実用化されている.

\section{4. おわりに}

執筆者のなかで $\mathrm{G}$ (Green) を積極的に意識しては執筆 された方は扮られなかった。これは社会生活の営みに直接 関係する部分の関心は高いものの，環境問題へのロボット 技術の応用という点ではまだ関心が低いことを意味してい るのかもしれない。最後に, 稲葉雅幸 (東大), 佐久間一郎 (東大) 両先生には執筆者をアレンジする際, 多大なるご協 力をいただきました。この場を借りてお礼申し上げます。

\section{参 考 文 献}

[1] 日本総合研究所, 日本ロボット学会, 人工知能学会, 日本人間工学会: ロボット分野に関するアカデミック・ロードマップ報告書. 2008.

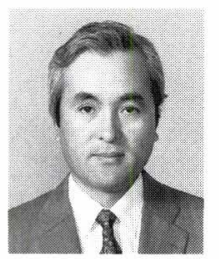

内山 隆 (Takashi Uchiyama)

1973 年東京工業大学大学院理工学研究科修士 課程修了. 工学博士. 現在, 富士通研究所取締 役兼）ビジネスインキュベーション研究所長・ ストレージ研究所長.ロボット・コンピュー 夕周辺機器の研究開発に従事.

(日本ロボット学会正会員)

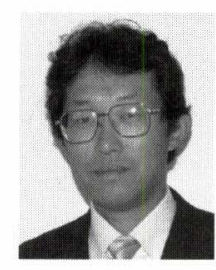

國井康晴（Yasuharu Kunii）

1997 年東京大学工学系研究科博士課程修了. 博士 (工学)。1994 1997 年学術振興会特別 研究員. 1997 年より中央大学講師, 現在同大 学准教授、遠隔制御, フィールドロボティク ス, 惑星探査システムの研究に従事.

(日本ロボット学会正会員)

\section{金子 真 (Makoto Kaneko)}

1981 年東京大学工学系研究科博士課程修了. 工学博士。通産省工業技術院機械技術研究所, 九州工業大学助教授, 広島大学教授を経て, 2006 年より大阪大学教授. ハイパーヒューマ ン技術の医療診断応用に興味をもつ。

(日本ロボット学会正会員) 